\title{
STRATEGI PEMASARAN SEKOLAH DASAR PERTIWI ABHILASA DALAM MENINGKATKAN JUMLAH SISWA
}

\author{
I Made Sugitayasa \\ Bintang Simbolon \\ bintangsmbln@yahoo.com \\ Lisa Gracia Kailola \\ graciakailola@gmail.com
}

\begin{abstract}
Abstrak
Penelitian ini bertujuan untuk mendeskripsikan: (1) mengetahui penyebab SD Pertiwi Abhilasa kurang diminati calon peserta didik dari umat Beragama Hindu, (2)menganalisis strategi yang dilakukan sekolah dalam meningkatkan jumlah peserta didik di Sekolah Dasar Pertiwi Abhilasa, dan (3) mengetahui evaluasi strategi pemasaran yang dilakukan SD Pertiwi Abhilasa.

Penelitian ini merupakanPenelitian deskriptif. Pendekatan yang digunakan adalah pendekatan kualitatif dengan metode deskriptif. Penelitian deskriptif, bukan hanya bisa mendeskripsikan sesuatu keadaan saja, tetapi bisa juga mendeskripsikan keadaan dalam tahapan perkembangannya.Subyek penelitian ini adalah Kepala Sekolah dan Orang Tua siswa.

Lokasi penelitian di Sekolah Dasar Pertiwi Abhilasa. Metode pengumpulan data dengan wawancara, observasi dan studi dokumentasi. Uji keabsahan data dengan trianggulasi sumber dan teknik. Adapun hasil penelitian menunjukkan sebagai berikut. (1) Analisis Pemasaran dilakukan dengan kegiatan menganalisis hasil pemasaran atau pencapaian tahun lalu meliputi strategi pemasaran yang digunakan media promosi. (2) Promosi yang dilakukan dengan media cetak, Open house dan media elektronik. (3) keberadaan sekolah ini yang berada di area tempat ibadah Umat Hindu menjadikan sekolah ini tidak begitu terlihat di masyarakat umum. (4) sarana dan prasarana yang ada di sekolah ini juga masih terbatas mengingat beberapa gedung dan ruangan yang seadanya dan dimanfaatkan semaksimal mungkin.Solusi yang ditawarkan adalah dengan melibatkan dan mengajak seluruh stakeholder sekolah Pertiwi Abhilasa dari siswa untuk ikut serta dalam kegiatan promosi.
\end{abstract}

Kata kunci: Strategi, Pemasaran, Jumlah, Meningkatkan. 


\begin{abstract}
This study aims to describe: (1) know the causes of Abtial Pertiwi Elementary School are less attractive to prospective students from Hinduism, analyze the strategies carried out by schools in increasing the number of students in SD PertiwiAbhilasa, (2)analyze the strategies carried out by schools in increasing the number of students in SD Pertiwiabhilasa, and (3) know the evaluation of strategies marketing conducted by SD Pertiwi Abhilasa.

This research is descriptive research. The approach used is a qualitative approach with descriptive methods. Descriptive research, not only can describe a situation, but can also describe the state in its developmental stage. The subjects of this study are the Principal and Parents of students.

The research location is in SD Pertiwi Abhilasa. Data collection methods by interview, observation and documentation study. Test the validity of the data with triangulation of sources and techniques. The results of the study show the following. (1) Marketing Analysis is carried out by analyzing marketing results or achievements in the past year including marketing strategies used by promotional media. (2) Promotions are carried out with print media, open houses and electronic media. (3) the existence of this school which is in the area of Hindu worship places makes this school not so visible in the general public. (4) facilities and infrastructure in this school are also still limited, considering that some buildings and rooms are modest and utilized to the maximum extent possible. The solution offered is to involve and invite all stakeholders of the Pertiwi Abhilasa school from students to participate in promotional activities.
\end{abstract}

Keywords: Strategy, Marketing, Amount, Increase. 


\section{A. PENDAHULUAN}

\section{Latar Belakang}

Telah menjadi realitas, bahwa persaingan antar sekolah saat ini semakin kompetitif. Hal ini tentunya menjadi sinyal positif dalam peningkatan kualitas penyelenggaraan pendidikan. Hal ini dapat dibuktikan dengan adanya upaya kreatif penyelenggara pendidikan untuk menggali keunikan dan keunggulan sekolahnya agar dibutuhkan dan diminati oleh pelanggan jasa pendidikan. Munculnya sekolah unggulan dengan kurikulum bertaraf Internasional serta lahirnya sekolah negeri dan swasta yang menawarkan keunggulan fasilitas, bahkan dengan biaya yang terjangkau, dapat menambah maraknya kompetisi pendidikan.

Saat ini, dunia pendidikan harus diperlakukan dan dikelola secara profesional, karena semakin ketatnya persaingan, lembaga pendidikan akan ditinggalkan konsumen atau masyarakat jika dikelola seadanya. Setiap lembaga pendidikan mengetahui bahwa proses pembelajaran di sekolah tidak akan pernah statis, akan tetapi senantiasa dinamis mengikuti kemajuan ilmu dan teknologi yang semakin hari semakin berkembang pesat. Untuk itu sekolah dituntut lebih meningkatkan kualitas pendidikan dari segala sisi.

"Lembaga pendidikan adalah sebuah kegiatan yang melayani konsumen berupa siswa dan masyarakat umum yang dikenal sebagai stakeholder. Lembaga pendidikan pada hakikatnya bertujuan untuk memberikan layanan dan pihak yang dilayani ingin memperoleh kepuasan dari layanan tersebut, karena mereka sudah membayar cukup mahal kepada lembaga pendidikan" Buchori Alma (2005:45-46). Pemasaran jasa pendidikan disini tergolong dalam marketing jasa yang "nonprofit oriented" atau perusahaan nirlaba. Dimana lembaga pendidikan tidak mencari keuntungan semata, demi kemakmuran para pengurus atau pemilik lembaga.

Sekolah adalah subsistem dari sistem sosial, karena itu, sekolah atau madrasah tidak memisahkan diri dari atau terasing dari masyarakatnya.Bagaimanapun, masukan siswa dan dana adalah berasal dari masyarakat. Lebih dari itu, di satu sisi sekolah memerlukan masyarakat dalam meyusun program yang relevan, sekaligus memerlukan dukungan dari masyarakat baik berupa calon murid/pendaftaran, maupun pembiayaan (SPP/DPP) dalam melaksanakan program sekolah, madrasah dan pesantren, Syafruddin (2005:272).

Sebuah lembaga yang ingin sukses untuk masa depan dalam menghadapi persaingan era globalisasi harus mempraktikkan pemasaran terus menerus agar mendapatkan jumlah siswa yang dikehendaki, karena semakin 
meningkatkan atau calon siswa yang masuk dapat mengangkat citra positif pada sebuah lembaga di masyarakat.Sebuah lembaga yang ingin sukses untuk masa depan dalam menghadapi persaingan era globalisasi harus mempraktikkan pemasaran terus menerus agar mendapatkan jumlah siswa yang dikehendaki, karena semakin meningkatkan atau calon siswa yang masuk dapat mengangkat citra positif pada sebuah lembaga di masyarakat, Nanang Fattah (2012:37).

Sekolah-sekolah yang memposisikan dirinya sebagai sekolah unggulan andalan ataupun favorit yang diregulasi pemerintah kota bukan menjadi pilihan utama bagi masyarakat saat ini, karena tren siswa dewasa ini ternyata tidak hanya melihat positioning sekolah unggulan, andalan dan favorit sebagai salah satunya pertimbangan untuk memutuskan bersekolah di lembaga tersebut, akan tetapi pertimbangan positioning sekolah gaul dan bonafide ternyata menjadi fenomena baru dalam pemasaran lembaga pendidikan, hal ini penting mendapat respon manajemen sekolah. Berkualitas, disiplin namun tetap gaul cenderung pula menjadi idealisme remaja serta sekolah bonafide dengan infrastruktur yang lebih mendukung, ruangan ber $\mathrm{AC}$, fasilitas teknologi yang memadai.

Hal ini ternyata merupakan perilaku konsumen pendidikan, siswa relatif ingin suasana dinamis dalam lingkungan sekolahnya, para wali murid pun ingin anaknya tahu banyak tentang teknologi pendidikan mutakhir, sehingga sekolah lagi-lagi dituntut menawarkan inovasi dalam programprogram apa saja yang akan ditawarkannya. Namun tidak hanya itu, yang lebih penting sebagai sikap yang harus dikembangkan adalah membangun persepsi dan citra positif (positive image) terlebih dahulu, mempunyai tujuan yang baik, saling mempercayai satu sama lain (mutual confidence), saling menghargai (mutual appreaciation), saling pengertian antar kedua belah pihak (mutual understanding) dan meliliki rasa toleransi (tolerance), Rosady Ruslan (1995:33).

Sekolah Dasar Pertiwi Abhilasa Berdiri pada tahun 2008, atas prakarsa beberapa orang tua murid TK yang menginginkan putra/putri tetap bersekolah dibawah payung Yayasan Pertiwi Abhilasa. Semua ini dikuatkan dengan 47 tanda tangan orangtua siswa. Atas dasar itulah, Yayasan Pertiwi Abhilasa membuka SD Pertiwi Abhilasa. Walaupun pada awalnya yang berkomitmen cukup banyak, namun hanya 4 orang yang memenuhi janjinya. Hal itu tidak menyurutkan semangat orang tua yang berkomitmen dan SD Pertiwi Abhilasa tetap berdiri.

Ruang lingkup kurikulum SD Pertiwi Abhilasa meliputi 2 bidang pengembangan, bidang pengembangan pembangunan karakter meliputi, Pengembangan Moral dan Nilai Agama dan Pengembangan Sosial Emosional dan Kemandirian. Sedangkan bidang pengembangan kemampuan dasar meliputi, Pengembangan Bahasa, Pengembangan Kognitif dan Pengembangan Fisik/Motorik.

Sekolah Dasar Pertiwi Abhilasa terletak di Jalan Daksinapati Raya Nomor 10. Rawamangun Jakarta timur. Sekolah ini berlokasi pura Aditya Jaya Rawamangun yang merupakan salah satu pura tempat ibadah umat Hindu yang berada di daerah Jakarta dan sekitarnya dengam jumlah umat KK 414 dengan total jiwa 1.412. Sekolah ini berada di wilayah strategis, yakni 
sebagai satu-satu sekolah yang memiliki peserta didik yang beragama Hindu dan menjadi sekolah umum di Jakarta.

Sekolah Dasar Pertiwi Abhilasa dalam proses belajar mengajar menggunakan kurikulum 2013, dengan lebih penekanan kepada pendidikan Agama Hindu, selain itu sekolah juga memiliki ekstrakurikuler yang beda dari sekolah lain yaitu dibidang kesenian tari-tarian Bali dan musik tradisonal Bali. Dengan dukungan dibidang kesenian membuat sekolah sering memenangkan kejuaraan dibidang kesian, selaain itu dalam kurun tiga tahun terakhir untuk nilai tertingi lulusan ujian nasional tingkat Sekolah Dasar Kecamatan Pulogadung, Sekolah Dasar Pertiwi Abhilasa selalu berada ditingkat tiga teratas, bahkan untuk tahun 2019 mendapat peringkat dua mengalahkan enam puluh tuju sekolah dasar di Kecamatan Pulogadung.

Untuk biaya yang ditawarkan Sekolah Dasar Pertiwi Abhilasa yakni Rp. 350.000 untuk perbulan, untuk siswa yang kurang mampu sekolah menawarkan subsidi silang dengan sistem sumbangan yang diambil dari orang tua siswa yang mampu secara perekoniman, selain itu sekolah juga mendapatkan bantuan dana dari PEMPROV DKI Jakarta beruapa kartu Jakarta pintar sebesar Rp. 130.000 perbulan.

Untuk mempromosikan sekolah Sekolah Dasar Pertiwi Abhilasa, pihak sekolah selama ini sudah melakukan teknik-teknik promosi diantaranya dengan penyebaran brosur sekolah di tempat-tempat yang dianggap memiliki peluang untuk mendapatkan pesera didik, sekolah juga banyak memasang spanduk-spanduk di tempat-tempat ibadah Agama Hindu di Jakarta timur, sekolah juga penah memasarkan sekolah di media berbagai media Hindu di jakarta dalam bentuk majalah dan televisi, namun hal tersebut tidak lagi dilakukan mengingat biaya yang mahal serta tidak berdampak juga terhadap kenaikan jumlah peserta didik. Sekolah juga sering mengisi acara dihari suci Keagamaan dengan menampilkan dibidang seni tari dan musik yang menjadi bagian dari strategi promosi sekolah, selain itu pihak sekolah menjalin kerjasama dengan orang tua siswa untuk ikut mempromosikan sekolah dilingkungan sosial tempat domisili ia berada.

Sekolah Pertiwi Abhilasaselama ini belum memiliki Website sehingga sekolah tidak bisa mengekspos kegiatan-kegiatan dan hal tersebut juga yang membuat sulitnya calon peserta didik untuk mencari informasi tentang Profil sekolah. Kendala lainnya yang dialami sekolah selama ini adalah masyarakat didekat lingkungan sekolah menanggap sekolah ini bukan sekolah reguler melainkan sekolah Agama Hindu, selain itu kurangnya biaya untuk mempromosikan sekolah membuat sekolah memberdayakan guru-guru dan orang tua siswa untuk ikut berpartisipasi dalam mempromosikan sekolah, namun hal itu belum maksimal mengingat saat ini masih kurangnya minat peserta didik untuk menyekolahkan anaknya di Sekolah Dasar Pertiwi Abhilasa.

Sekolah Dasar Pertiwi Abhilasa telah terakreditasi A, Sekolah memiliki delapan ruangan, enam ruangan belajar megajar, satu ruangan UKS dan satu ruangan perpustakaan.Jumlah tenaga karyawan di Sekolah Dasar 
Pertiwi Abhilasa tahun pelajaran 2008- 2019 berjumlah 8 orang, 6 orang merupakan tenaga pengadministrasi atau TU yang bertugas membantu, melayani, mengarahkan atau mengatur semua kegiatan administrasi sekolah. Selain 6 orang TU, terdapat pula 1 orang pegawai bidang kesehatan (UKS) Adapun 1 orang penjaga sekolah merupakan karyawan yang kegiatannya menjaga lingkungan sekolah agar tidak terjadi peristiwa yang dapat mengganggu jalannya proses belajarmengajar, dan tambahan tiga tenaga pengajar dari luar untuk ekstrakurikuler dibidang tari, musik dan bahasa Inggris.Dari sarana prasarana sekolah saat ini tidak begitu memadai karena sekolah saat ini tidak memiliki ruangan komputer sehingga pihak sekolah mewajibkan peserta didiknya untuk membawa laptop dari rumah.

Selama ini yang menjadi masalah bagi Sekolah Dasar Pertiwi Abhilasa adalah jumlah siswa yang dari tahun ketahun belum mengalami kenaikan yang signifikan, hal ini dikarenakan kurang maksimalnya strategi pemasaran dan sarana prasana sekolah yang perlu melakukan perbaikan karena keadaan gedung yang sudah banyak mengalami kerusakan, untuk tahun 2018-2019 sekolah memilik 51 peserta didik, sekolah terletak di tempat Ibadah Agama Hindu dengan jumlah KK 414 dengan total jiwa 1.412, sekolah yang telah terakreditasi A, dengan prestasi yang bagus dibidang kelulusan, serta memiliki ekstrakurikuler seni tari dan musik tradisional, dari sini penulis tertarik untuk melakukan penelitian terkait dengan "Stategi pemasaran Sekolah Dasar Pertiwi Abhilasadalam meningkatkan jumlah siswa".

\section{B. KAJIAN TEORI}

Penentuan strategi pemasaran harus didasarkan atas analisis lingkungan eksternal dan internal organisasi. Faktor-faktor eksternal yang dapat menimbulkan adanya peluang atau ancaman bagi organisasi terdiri atas: keadaan pasar, persaingan, teknologi, ekonomi, sosial budaya, hukum, dan peraturan. Sedangkan faktor-faktor internal menunjukkan adanya keunggulan atau kelemahan organisasi, meliputi: keuangan, produksi, SDM, serta khususnya bidang pemasaran yang terdiri dari produk, harga, distribusi, dan promosi. Analisis tersebut merupakan penilaian apakah strategi pemasaran yang telah ditetapkan dan dijalankan sesuai dengan keadaan pada saat ini. Hasil penilaian tersebut digunakan sebagai dasar untuk menentukan apakah strategi yang sedang dijalankan perlu diubah serta untuk menyusun atau menentukan strategi yang akandijalankan di masa mendatang.

Fandy Tjiptono (1999:43) menyatakan bahwa "strategi pemasaran adalah rencana yang hendak diikuti oleh manajer pemasaran. Rencana tindakan ini didasarkan atas analisa situasi dan tujuan-tujuan perusahaan dan merupakan cara untuk pencapaian tujuan tersebut". Menurut Sofyan Assauri strategi pemasaran adalah: Serangkaian tujuan dan sasaran, kebijakan dan aturan yang memberi arah kepada usaha-usaha pemasaran perusahaan dari waktu ke waktu, pada masing-masing tingkatan dan acuan serta alokasinya, terutama sebagai tanggapan perusahaan dalam menghadapi lingkungan dan keadaan persaingan yang selalu berubah. Oleh karena itu, penentuan strategi pemasaran harus didasarkan atas analisa lingkungan dan internal perusahaan 
melalui analisa keunggulan dan kelemahan perusahaan, serta analisa kesempatan dan ancaman yang dihadapi perusahaan dari lingkungannya, Soufyan Assauri (1988:153-155).

Dengan demikian, strategi pemasaran adalah serangkaian tujuan dan sasaran, kebijakan dan aturan yang memberi arah kepada usaha-usaha pemasaran yang dilakukan oleh sekolah dari waktu ke waktu, pada masing-masing tingkatan dan acuan serta alokasinya, terutama sebagai tanggapan lembaga sekolah dalam menghadapi lingkungan dan keadaan persaingan yang selalu berubah. Oleh karena itu, penentuan strategi pemasaran harus didasarkan atas analisa lingkungan dan internal sekolah melalui analisa keunggulan dan kelemahan sekolah, serta analisa kesempatan dan ancaman yang dihadapi sekolah dari lingkungannya.

Di samping itu strategi pemasaran sebagai alternatif, menurut Kotler dan Fox (1995) mengidentifikasi tiga unsur penting dari perumusan strategi pemasaran, yang bertujuan untuk memastikan bahwa organisasi berperan di pasar dengan cara yang paling efektif. Ketiga unsur tersebut adalah sebagai berikut, David Wijaya(2012:55) :

a. Strategi Penentuan Pasar Sasaran (Target Market Strategy).

Strategi ini bertujuan untuk mengidentifikasi segmen pasar jasa pendidikan tertentu dari total pasar jasa pendidikan. Pemasar jasa pendidikan hanya berfokus pada segmen pasar jasa pendidikan itu. Segmentasi pasar adalah tindakan mengidentifikasikan dan membentuk kelompok pembeli atau konsumen secara terpisah. Masing-masing segmen konsumen ini memiliki karakteristik, dan kebutuhan produk.

Berdasarkan informasi yang diperoleh pemasar, maka pasar, potensial dapat dikategorikan dengan empat cara:

1) Segmentasi Demografi, Membagi pasar dalam beberapa kelompok berdasarkan karakteristik sebagai usia, pendidikan, jenis kelamin, penghasilan, dan jumlah keluarga.

2) Segmentasi Geografi, Mengindentifikasi tempat atau wilayah dimana pasar berada, misalnya besarnya wilayah, iklim, kepadatan penduduk, atau kondisi fisik pasar.

3) Segmentasi Psikografi, Segmentasi pasar berdasarkan gaya hidup dan kepribadian konsumen seperti aktivitas seorang, selera, minat atau opini.

4) Segmentasi Manfaat, Pembagian pasar yang lebih memfokuskan pada manfaat yang diharapkan dari suatu produk daripada karakteristik konsumen itu tersendiri, Hemmy Fauzan (2006:108).

b. Strategi Penentuan Posisi Pasar Persaingan (Competitive PositioningStrategy)

Strategi ini bertujuan untuk mengidentifikasi atribut sekolah yang berbeda-beda sehingga membuat sekolah berbeda dari kompetitornya yang beroperasi pada segmen pasar jasa pendidikan yang sama. Tujuan positioning ini adalah untuk membangun dan mengkomunikasikan keunggulan bersaing produk yang ada di pasar ke dalam benak konsumen, Freddy Rangkuti (2011:49).

c. Strategi Bauran Pemasaran (Marketing Mix Strategy) 
Strategi ini merupakan perpaduan dari berbagai unsur yang disajikan sekolah kepada pelanggan jasa pendidikan untuk mempromosikan jasa pendidikan yang dimilikinya. Untuk keberhasilan sebuah perusahaan atau lembaga dalam jangka panjang, maka perusahaan atau lembaga tersebut harus menciptakan layanan yang memuaskan kebutuhan dan keinginan pelanggannya.

Pemasaran jasa pendidikan akan menawarkan jasa pendidikan dengan bauran pemasan yang terdiri atas tujuh alat pemasaran jasa pendidikan, yang juga dikenal dengan istilah 7P." Wijaya (2011:75). Penjabaran dari 7P (Product, Price, Promotion, Place, People,Process, and Physical Evidence) adalah sebagai berikut:

1) Product (Produk)

2) Price (Harga)

3) Promotion (Promosi)

4) Place (Tempat)

5) People (Orang)

6) Physical Evidence (Bukti Fisik)

\section{Pemasaran Jasa Pendidikan}

Suatu perusahaan atau lembaga yang memproduksi barang ataupun jasa untuk memperkenalkan produknya kepada masyarakat sebagai konsumen maka diperlukan kegiatan pemasaran. Pemasaran merupakan penghubung organisasi dengan konsumennya. Pada pemasaran berlangsung proses mengkomunikasikan berbagai hal yang terdapat dalam suatu lembaga kepada masyarakat luas dengan tujuan menarik minat masyarakat atau mempengaruhi harapan masyarakat.

Menurut Philip Kotler menyatakan "pemasaran adalah suatu proses sosial yang di dalamnya individu dan kelompok mendapatkan apa yang mereka butuhkan dan inginkan dengan menciptakan, menawarkan dan secara bebas mempertukarkan produk yang bernilai dengan pihak lain", Tim Dosen Administrasi Pendidikan (2013:337).

Definisi dari Marketing Association of Australia dan New Zealand (MAANZ) pemasaran adalah aktivitas yang memfasilitasi dan memperlancar suatu hubungan pertukaran yang saling memuaskan melalui penciptaan, pendistribusian, promosi dan penentuan harga dari barang, jasa dan ide, Buchari Alma (2013:3). Menurut Basu Swastha dan Ibnu Sukotjo "pemasaran adalah sistem keseluruhan dari kegiatan usaha yang ditujukan untuk merencanakan, menentukan harga, dan mendistribusikan barang dan jasa yang dapat memuaskan kebutuhan kepada pembeli yang ada atau pembeli yang potensial" Basu Swastha (1991:79).

Dari pengertian di atas, maka dapat disimpulkan bahwa pemasaran jasa pendidikan adalah upaya-upaya yang dilakukan secara terpadu untuk menggabungkan rencana-rencana strategis yang diarahkan kepada usaha dalam pemuasan kebutuhan dan keinginan costumer dengan menyebarkan nilai-nilai positif untuk masyarakat luas dengan menciptakan, menawarkan produk atau jasa kepada masyarakat guna meningkatkan mutu layanan pendidikan. 


\section{Fungsi Dan Tujuan Pemasaran Pendidikan}

Fungsi pemasaran pada organisasi yang berorientasi pada laba (perusahaan) dengan organisasi nirlaba (sekolah) sangat berbeda. Fungsi pemasaran ini secara lebih luas akan dijabarkan dalam bauran pemasaran yaitu merupakan sarana mencapai tujuan pemasaran (marketingobjective), Rusadi Rulan (2008:230). Perbedaannya fungsi terletak pada cara kedua organisasi tersebut memperoleh sumber dana yang diperlukan untuk melakukan operasinya.Fungsi dari pemasaran pendidikan adalah "sebagai langkah pembaharuan ketika sebuah lembaga pendidikan harus mengikuti atau mengimbangi ketatnya persaingan dalam memperoleh pelanggan (customer)", Tim Dosen Administrasi Pendidikan (2013:348).

Untuk menentukan tujuan maupun fungsi dari pemasaran pendidikan, tentunya tidak akan dapat terlepas dari pengertian yang telah disampaikan di atas.Tim Dosen Administrasi Pendidikan (2013:349), adapun beberapa tujuan dari pemasaran pendidikan adalah

a. Memberi informasi kepada masyarakat tentang produk-produk lembaga pendidikan,

b. Meningkatkan minat dan ketertarikan masyarakat pada produk lembaga pendidikan,

c. Membedakan produk lembaga pendidikan dengan lembaga pendidikan yang lain,

d. Memberikan penilaian lebih pada masyarakat dengan produk yang ditawarkan, dan

e. Menstabilkan eksisensi dan kebermaknaan lembaga pendidikan di masyarakat.

Dari beberapa tujuan pemasaran pendidikan dapat disimpulkan yang ingin dicapai dari pemasaran pendidikan adalah mendapatkan pelanggan yang disesuaikan dengan target, baik itu yang berkaitan dengan kualitas maupun kuantitas dari calon pelanggan (siswa).

\section{Analisis SWOT}

Analisis SWOT merupakan teknik historis yang terkenal dimana para manajer menciptakan gambaran secara umum secara cepat mengenai situasi strategis perusahaan. John A. Pearce (2007:200) Analisis SWOT mengidentifikasi peluang dan ancaman eksternal, mengukur dan menetapkan kelemahan dan kekuatan internal, serta menetapkan tujuan jangka panjang. Jika dalam bidang pendidikan yakni apabila sekolah akan menyusun RPS dengan alternatif kedua harus menggunakan analisis SWOT sebagai satu langkah yang di tempuh. Analisis SWOT dilakukan dengan maksud mengenali tingkat kesiapan setiap fungsi dari keseluruhan fungsi yang diperlukan untuk mencapai sasaran yang telah ditetapkan.

Menurut Akdon (2009:106), organisasi hidup dalam suatu sistem yang saling berhubungan dan mempengaruhi, sehingga untuk mempertahankan eksistensinya, organisasi perlu mengenali dan menguasai berbagai informasi lingkungan strategiknya. Untuk mendapatkan strategi yang tepat dan valid, perlu dilakukan suatu analisis lingkungan strategik. Yang dimaksud di sini meliputi kondisi, situasi, keadaan, peristiwa dan 
pengaruh-pengaruh di dalam dan disekeliling organisasi yang berdampak pada kehidupan organisasi berupa kekuatan internal, kelemahan internal, peluang eksternal dan tantangan eksternal.

a. Lingkungan Internal, meliputi:

1) Kekuatan (Strenght) adalah situasi dan kemampuan internal yang bersifat positif yang memungkinkan organisasi memenuhi strategik dalam mencapai visi dan misi

2) Kelemahan internal (Weakness) adalah situasi dan faktor-faktor dalam organisasi yang bersifat negatif, yang menghambat organisasi mencapai atau mampu melampaui pencapaian visi dan misi

b. Lingkungan Eksternal, meliputi:

1) Peluang (Opportunity) adalah situasi dan faktor-faktor luar organisasi yang bersifat positif, yang membantu organisasi mencapai atau mampu melampaui pencapaian visi dan misi.

2) Tantangan/ancaman (Threat) adalah faktor-faktor luar organisasi yang bersifat negatif, yang dapat mengakibatkan organisasi gagal dalam mencapai visi dan misi

\section{METODELOGI PENELITIAN}

Pendekatan yang digunakan adalah pendekatan kualitatif dengan metode deskriptif. Penelitian deskriptif, bukan hanya bisa mendeskripsikan sesuatu keadaan saja, tetapi bisa juga mendeskripsikan keadaan dalam tahapan perkembangannya. Sukmadinata (2012:54) menyatakan "penelitian deskriptif adalah suatu metode penelitian yang tertuju untuk menggambarkan fenomenafenomena yang ada, yang berlangsung pada saat ini atau saat yang lampau". Metode kualitatif digunakan untuk mendapatkan data yang mendalam, dan mengandung makna yang sebenarnya. Dalam penelitian kualitatif tidak menekankan pada generalisasi, tetapi lebih menekan pada makna.

Dalam penelitian kualitatif, yang menjadi instrumen adalah peneliti itu sendiri. Peneliti sebagai instrumen juga "divalidasi" seberap jauh peneliti kualitatif siap terjun ke lapangan. Instrumen penelitian diharapkan dapat melengkapi data dan membandingkan dengan yang telah ditemukan melalui pedoman wawancara, pedoman observasi dan studi dokumentasi.

Uji kredibilitas dilakukan untuk menyakinkan bahwa data yang ditampilkan benar-benar kredibel dan valid sehingga tidak diragukan lagi tingkat kebenarannya. Sugiyono (2013:121) menyatakan bahwa: "uji kredibilitas data atau kepercayaan terhadap data hasil penelitian kualitatif antara lain dilakukan dengan perpanjangan pengamatan, peningkatan ketekunan dalam penelitian, triangulasi, diskusi dengan teman sejawat, analisis kasus negatif, dan membercheck".

Pengumpulan data dapat dilakukan dalam berbagai setting, berbagai sumber, dan berbagai cara. Bila dilihat dari setting-nya, data dapat dikumpulkan pada setting alamiah (natural setting) seperti laboratorium dengan metode eksperimen. Selanjutnya bila dilihat dari segi cara atau teknik pengumpulan data, maka dapat dilakukan dengan wawancara, observasi, dan dokumentasi. Setelah proses pengumpulan data dilakukan, selanjutnya melakukan analisis data. Data dan informasi yang telah diperoleh akan dianalisis dengan pola 
kualitatif dan diinterpretasikan secara terus menerus mulai awal penelitian sampai berakhir penelitian. Proses penganalisian dilaksanakan bertujuan untuk membantu peneliti memudahkan dan menyelenggarakan tumpukan data yang diperoleh, sama ada disimpan data tersebut atau dikesampingkan apabila tidak memenuhi kehendak pertanyaan penelitian.

\section{PEMBAHASAN}

Kondisi fisik sekolah merupakan elemen yang penting untuk menunjang minat orang tua siswa untuk menyekolahkan anaknya, fisik sekolah meliputi kondisi fisik interior dan eksterior sekolah, diantaranya:

1. Interior sekolah meliputi kondisi ruangan belajar, ruangan perpustakaan, ruangan guru, ruangan UKS, ruangan komputer, dan ruangan toilet sekolah.

2. Eksterior skolah meliputi kondisi gedung, tempat bermain siswa, dan parkir sekolah.

Berdasarkan pernyataan Kepala Sekolah Dasar Pertiwi Abhilasa di atas bahwa penyebab tidak tertariknya orang tua siswa untuk menyekolahkan anakanaknya dikarenakan kondisi fisik sekolah yang perlu adanya perbaikan. perbaikan kondisi fisik selama ini terganggu dengan kondisi dimana sekolah tidak memiliki hak untuk melakukan perbaikan dikarenakan gedung sekolah merupakan bagian dari arena tempat ibadah yang para pengurus tempat ibadah tidak antusias dalam membantu memperbaiki keadaan sekolah.Ruangan belajar di Sekolah Dasar Pertiwi Abhilasa banyak mendapatkan keluhan dari orang tua murid dikarenakan ruangan belajar masih menggunakan kipas angin berbeda dengan kebanyakan sekolah yang sudah menggunakan AC sebagai sarana dan prasarana untuk menunjang kenyamanan belajar peserta didik.

Penulis banyak mendapatkan banyak keluhan mengenai sekolah yang tidak memiliki ruangan UKS khusus, dimana saat ini untuk sementara ruangan UKS digabung dengan ruangan guru hanya di sekat dengan gorden, hal ini disiasati oleh kepala sekolah karena keterbatasan ruangan yang dimiliki oleh sekolah. Selain itu, Dari hasil wawancara dengan orang tua murid mereka menyatakan bahwa Sekolah Pertiwi Abhilasa tidak memiliki ruangan perpustakaan, kegiatan membaca atau budaya literasi di sini hanya di lakukan di dalam kelas saja. Sehingga peserta didik tidak memiliki kegiatan positif tambahan untuk meningkatkan pengetahuan mereka memalui membaca.Dari hasil wawancara dengan orang tua siswa mendapatkan data bahwa sekolah tidak memiliki ruangan olah raga, hal ini menjadi ketakutan bagi orang tua siswa yang tidak ingin anaknya bermain hal-hal yang tidak bersifat positif bagi mereka, selain itu orang tua siswa juga berharap dengan adanya ruang olahraga sekolah juga dapat menunjang prestasi peserta didik dibidang olahraga, dari kondisi tersebut banyak dari orang tua siswa memilih mengeluarkan uang lebih untuk mencarikan kegiatan olahraga di luar Sekolah Pertiwi Abhilasa.Saat ini sekolah tidak memiliki ruangan olah raga dikarenakan ruangan olahraga yang dulu yang sering dipakai sekolah mengalami renovasi dari pihak pengelola tempat ibadah.

Dari data yang diperoleh mengenai penyebab SD Pertiwi Abhilasa kurang diminati calon peserta didik dari umat beragama Hindu karena saat ini kondisi 
fisik sekolah memang perlu adanya perbaikan dimana interior sekolah yang masih kurang seperti ruangan belajar yang belum memiliki AC, jumlah ruangan yang sedikit menyebabkan sekolah tidak memiliki ruangan perpustakaan dan ruangan komputer. Dari ekterior Sekolah saat ini meliputi kondisi gedung dari luar yang nampak seperti tidak terurus oleh pihak pengelola tempat ibadah, dan ruangan bermain untuk peserta didik yang masih kurang karena tidak tersedia tempat olah raga yang layak. Hal tersebut yang menyebabkan Sekolah Pertiwi Abhilasa kurang diminati oleh umat Hindu di Jakarta.Untuk mengetahui evaluasi stategi pememasaran Sekolah Dasar Pertiwi Abhilasa, maka digunakan teknik analisis SWOT untuk mendapatkan informasi yang lebih mendalam melalui wawancara dengan Kepala Sekolah SD Pertiwi Abhilasa seperti berikut:

a. Kekuatan SD Pertiwi Abhilasa dalam Hal Pemasaran (Strength)

Kekuatan sekolah merupakan hal yang di unggulkan oleh sekolah, keunggulan ini yang akan menjadi daya tarik tersendiri bagi calon peserta didik untuk menentukan sekolah yang akan mereka pilih. Kekuatan sekolah juga dapat dijadikan sebagai strategi dalam memasarkan sekolah. Untuk bersaing dengan kompetitor sekolah-sekolah lain setiap sekolah menawarkan keunggulan-keunggulan mereka masing-masing, baik itu di bidang fasilitas, akademik dan SDM yang mereka miliki, kekuatan adalah kemauan internal Sekolah yang bersifat positif yang memungkinkan Sekolah memenuhi strategi untuk mencapai visi dan misi. Lalu bagaimana dengan kekuatan dari SD Pertiwi Abhilasa.

Dari hasil wawancara dengan Kepala Sekolah Pertiwi Abhilasa, beliau menyatakan bahwa out come atau hasil dari proses belajar mengajar yang diberikan oleh Sekolah kepada peserta didik, hal ini dibuktikan dengan prestasi-prestasi sekolah selama ini di bidang akademis dan bidang keagamaan, di bidang akademis mereka selalau mendapatkan nilai yang memuaskan saat mengikuti Ujian Nasiomal (UN), di bidang keagamaan peserta didik Sekolah Dasar Pertiwi Abhilasa selalau bisa menembus Uutsawa Dharma Gita(UDG) yang merupakan kegiatan keagamaan Hindu tinggat nasional, dimana peserta terlebih dahulu mengikuti seleksi tingkat daerah sebelum bertanding di tingkat nasioal dengan membawa nama daerahnya masing-masing. Dari prestasi ini menunjukkan bahwa Sekolah Dasar Pertiwi Abhilasa sudah berhasil mendidik peserta didik dibidang keagamaan, dari segi pengembangan karakter menurut beliau rata-rata orang tua peserta didik sudah puas dengan karaker baik yang dimiliki oleh anaknya sesuai dengan visi sekolah yaitu membangun manusia yang memiliki pengetahuan, keterampilan, budi pekerti, etika dan melestarikan budaya leluhur serta mengembangkan jiwa nasionalisme dan misi Sekolah yaitu membangun pemahaman ajaran agama yang baik dan benar untuk mewujudkan harmonisasi rasa bhakti kepada Tuhan Yang Maha Esa, kepada sesama manusia, dan alam sekitarnya.

\section{b. Kelemahan SD Pertiwi Abhilasa dalam Hal Pemasaran (Weakness)}

Kelemahan Sekolah merupakan hal yang harus diperbaiki secepatnya oleh pihak sekolah tersebut, karena dari kelemahan sekolah akan memberikan dampak terhadap proses keberhasilan startegi pemasaran sekolah, dimana 
calon peserta didik tidak hanya memilihat kekuatan sekolah tersebut, mereka juga akan mempertimbangkan kelemahan sekolah, kelemahan merupakan situasi dan faktor-faktor dalam Sekolah yang bersifat negatif, yang akan menghambat Sekolah mencapai visi dan misi.

Dari hasil wawancara dengan Kepala Sekolah, beliau menyatakan bahwa selama ini yang menjadi kelemahan Sekolah dalam memasarkan jasa pendidikan adalah fisik sekolah yang memilupi kondisi gedung dan jumlah ruangan yang ada, karena sampai saat ini Sekolah belum memiliki ruangan perpustakaan, ruangan komputer dan tempat olah raga bagi peserta didik. Kelemahan ini menurut beliau masih menjadi kekurangan Sekolah yang sampai saat ini belum mendapat solusi dari pihak pengelola tempat ibadah, kurang antusiasnya pengelola Pura untuk membantu memfasilitasi Sekolah menyebabkan terganggunya proses pemasaran Sekolah Dasar Pertiwi Abhilasa saat ini.

\section{c. Peluang SD Pertiwi Abhilasa dalam Pemasaran (Opportunity)}

Peluang sekolah merupakan apa yang bisa dimanfaatkan oleh sekolah untuk menarik calon peserta didik yang lebih banyak kedepannya, peluang ini harus dapat diketahui oleh sekolah sehingga bisa dikelola dengan baik, karena keberhasilan suatu Sekolah juga dipengaruhi oleh bagaimana pihak Seolah dapat memanmfaatkan peluang dengan baik, peluang adalah situasi dan faktor-faktor luar oganisasi Sekolah yang bersifat positif, yang membantu Sekolah mencapai atau mampu melampaui capaian visi dan misi.

Dari hasil wawancara dengan Kepala Sekolah Pertiwi Abhilasa, beliau menyatakan bahwa peluang Sekolah Dasar Pertiwi Abhilasa dalam melihat peluang pemasaran adalah dari Output peserta didik yang sangat bagus hal ini didukung dari hasil belajar mengajar sekolah yang bagus dengan kinerja tenaga pendidik yang memuaskan yang dimiliki Sekolah saat ini. Hasil lulusan dari Sekolah Dasar Pertiwi Abhilasa terus dimonitor oleh Sekolah, pihak sekolah menjalin komukasi yang baik dengan alumnialumni sekolah dan dari informasi yang mereka dapatkan data bahwa lulusan dari sekolah tersebut mampu bersaing di Sekolah Menengah Pertama (SMP), Sekolah Menengah Atas (SMA) dan Perguruan Tinggi, bahkan lulusan mereka merupakan anak-anak yang memiliki prestasi yang bagus. Ini artinya bahwa dari proses belajar yang mereka dapat di Sekolah Dasar Pertiwi Abhilasa membuat mereka mampu bersaing di Sekolah mereka selanjutnya.

Ini menjadi peluang bagi mereka, karena Sekolah yang menciptakan lulusan-lulusan yang berkualitas, dari hasil lulusan ini akan menjadi peluang bagi sekolah untuk memasarkan jasa pendidikan, karena calon peserta didik terkhususnya orang tua mereka akan tertarik untuk menyekolahkan anaknya di Sekolah Dasar Pertiwi Abhilasa karena mereka tau akan lulusan dari sekolah tersebut yang tidak hanya mampu bersaing bahkan memiliki prestasi yang bagus di jenjangan pendidikan selanjutnya. 


\section{d. Ancaman atau Tantangan SD Pertiwi Abhilasa dalam Hal Pemasaran (Threats)}

Ancaman atau tantangan sekolah swasta saat ini adalah dimana kebijakan pemerintah mengenai pendidikan gratis bagi peserta didik yang masuk di Sekolah SD dan SMP negeri, ini menyebabkan banyak calon peserta didik yang memilih sekolah negeri ketimbang sekolah swasta yang harus bayar, Sekolah negeri tidak pernu memungut biaya kepada peserta didik karena pemerintah memberikan Bantuan Oprasional Sekolah (BOS) bantuan ini diberikan berdasarkan jumlah peserta didik yang dimiliki oleh sekolah negeri tersebut, bagi orangg tua yang tidak mampu mereka akan memilih menyekolahkan anaknya di sekolah gratis untuk mengurangi beban ekonomi mereka. Namun berbeda halnya dengan mereka yang mampu dibidang ekonomi, uang bagi mereka bukanlah penghalang demi mendapatkan pendidikan yang lebih baik, mereka yang tidak puas dengan fasilitas yang diberikan oleh sekolah negeri akan memilih sekolah swasta yang mampu memberikan fasilitas pendidikan yang lebih baik walaupun harus membayar dengan harga yang mahal.

Dari hasil wawancara dengan Kepala Sekolah Pertiwi Abhilasa, beliau menyatakan bahwa yang menjadi ancaman atau tantangan Sekolah dalam hal pemasaran adalah dari umat mereka sendiri yang tidak mau mempercayakan anaknya untuk menjadi peserta didik di Sekolah tersebut. Ini terbukti dengan lokasi yang terletak di tempat ibadah Agama Hindu yang pertama di Jakarta yang diresmikan sejak tahun 1993, dari data yang diberikan oleh pihak pengelola Pura, umat yang bergabung diorganisasi pura berjumlah $414 \mathrm{KK}$ dengan total jiwa 1.412 , sedangkan pada tahun pendidikan 2018-2019 Sekolah Dasar Pertiwi Abhilasa hanya memiliki 51 peserta didik.

Kurangnya militansi dari umat Hindu yang berada di Jakarta menjadi ancaman bagi Sekolah Pertiwi Abhilasa, dimana umat Hindu lebih memilih menyekolahkan anaknya di Sekolah lain ketimbang sekolah tersebut yang merupakan sekolah satu-satunya yang didirikan khusus bagi umat Hindu di Jakarta yang ingin anaknya mendapatkan pejaran Agama Hindu secara mendalam serta sekolah satu-satunya di Jakarta yang menyediakan Ekskul Bahasa bali.

\section{E. KESIMPULAN}

Penyebab Sekolah Dasar Pertiwi Abhilasa kurang diminati oleh peserta didik, diantaranya adalah kondisi fisik sekolah yaitu dari interior dan eksterior Sekolah yang masih banyak kekurangan. Di bagian interior yang banyak dikeluhkan oleh orang tua peserta didik diantaranya ruang belajar siswa yang masih menggunakan kipas angin sebagai penyejuk ruangan, seharusnya pihak Sekolah menyediakan AC di ruangan belajar siswa untuk membuat kelas lebih nyaman dalam mengikuti proses belajar. Sekolah saat ini belum memiliki ruangan perpustakaan, ini merupakan hal wajib seharusnya disediakan oleh Sekolah karena perpustakaan sangat membantu sebagai referensi tambahan ilmu pengetahuan bagi peserta didik. Sekolah Dasar Pertiwi Abhilasa juga saat ini belum memiliki ruangan komputer, di era abad 21 ini pelajaran komputer 
sangat penting bagi peserta didik karena Ujian Nasional saat ini menggunakan komputer sebagai media ujian serta sekolah juga tidak memiliki tempat khusus untuk ruangan UKS. Sedangkan dari eksterior Sekolah yang menjadi penyebab Sekolah Dasar Pertiwi Abhilasa kurang diminati oleh peserta didik diantaranya adalah kondisi gedung Sekolah yang tidak menarik karena sudah perlu diperbaiki, selain itu Sekolah juga tidak menyediakan tempat olah raga yang layak bagi peserta didik.

Strategi pemasaran Sekolah Dasar Pertiwi Abhilasa yang selama ini dilakukan adalah diantaranya dari hal-hal yang bersifat simbiosis yaitu ekskul musik tradisional Bali, tari tradisonal Bali dan Bahasa dearah Bali, Sekolah juga unggul dibidang lulusan peserta didik yang banyak diterima di Sekolah favorit di Jakarta. Selain itu sekolah juga memiliki lokasi yang strategis dengan akses yang mudah karena banyak tersedia kendaraan umum yang mempermudah peserta didik untuk sampai di Sekolah, serta lalu lintas yang memadai. Sekolah juga memiliki tenaga pendidik yang menghasilkan peserta didik yang berprestasi dibidang akademis serta sekolah juga unggul dari segi harga yang lebih murah dari kompetitor Sekolah swasta yang ada di Kecamatan Pulogadung dengan bantuan KJP dan subsidi silang.

Sekolah Dasar Pertiwi Abhilasa menerapkan strategi promosi sekolah dengan menyebar flayer di sekolah-sekolah yang ada di Kecamatan Pulogadung, Sekolah juga melakukan penjualan pribadi dengan memasarkan langsung jasa pendidikan ke calon peserta didik, strategi penjualan pribadi dianggap yang paling efektif dalam mendapatkan calon peserta didik baru, selain itu sekolah juga memasang spanduk yang berisikan tentang informasi dan prestasi-prestasi Sekolah di tempat-tempat ibadah Agama Hindu yang ada di Jakarta.

Sekolah Dasar Pertiwi Abhilasa melakukan evaluasi startegi pendidikan untuk mengoptimalkan pemasaran dengan cara terus meningkatkan SDM yang dimiliki lembaga pendidikan saat ini. Sekolah Dasar Pertiwi Abhilasa mengelola kelemahan Sekolah menjadi peluanguntuk mengoptimalkan pemasaran dengan cara menunjukkan prestasi Sekolah melaui media cetak agar diketahui oleh calon peserta didik.

Sekolah Dasar Pertiwi Abhilasa dalam mengelola kekuatan Sekolah untuk menghadapi pesaing sekolah dengan cara terus meningkatkan prestasi akademis sekolah yang dimiliki Sekolah, meningkatkan kualitas SDM dengan mengikut sertakan tenaga pendidik untuk mengikuti seminar-seminar pelatihan agar guru dapat menciptakan peserta didik yang berprestasi. Dalam menghadapi tantangangan pemasaran Sekolah untuk menghadapi ancaman pesaing Sekolah menjadi permasalahan yang sampai saat ini belum bisa diatasi, lembaga pendidikan Pertiwi Abhilasa menerima kenyataan bahwa mereka belum menjadi pilihan utama dibandingkan dengan sekolah-sekolah di Kecamatan Pulogadung, seperti sekolah-sekolah swasta yang menyediakan falisitas yang lebih baik, dan sekolah-sekolah negeri yang memeberiakan fasilitas bagus tanpa memunggut biaya dari peserta didik. 


\section{F. SARAN}

Dari hasil penelitian mengenai strategi promosi Sekolah untuk peningkatan jumlah siswa di Sekolah Dasar Pertiwi Abhilasa, dapat disarankan beberapa hal sebagai berikut:

1. Sekolah hendaknya mencari donatur yang mau membantu merelokasi keberadaan Sekolah Dasar Pertiwi Abhilasa ke tempat yang lebih strategis karena selama ini sekolah yang berada di lingkungan Pura menyebabkan Sekolah kurang diminati oleh masyrakat umum, selain itu pihak pengelola pura juga tidak antusias terhadap kebutuhan Sekolah.

2. Sekolah Dasar Pertiwi Abhilasa hendaknya mengupayakan AC untuk ruangan belajar siswa untuk menunjang strategi pemasaran.

3. Sekolah Dasar Pertiwi Abhilasa hendaknya mengupayakan tersedianya tempat olah raga siswa untuk menunjang strategi pemasaran.

4. Sekolah Dasar Pertiwi Abhilasa hendaknya mengupayakan ruangan perpustakaan untuk menunjang strategi pemasaran.

5. Sekolah Dasar Pertiwi Abhilasa harus membuat event yang bersifat umum dengan mengundang sekolah-sekolah yang ada di Kecamatan Pulogadung sebagai strategi pemasaran Sekolah.

6. Sekolah Dasar Pertiwi Abhilasa hendaknya memiliki Website dan sosial media untuk mempermudah mengakses informasi Sekolah.

\section{DAFTAR PUSTAKA}

Agustina Shinta, Manajemen Pemasaran, (Malang: Universitas Brawijaya Press, 2011)

Aan Komariah dan Cepi Triatna, Visionary Leadership: Menuju Sekolah Efektif, (Jakarta: PT Bumi Aksara, 2005)

Akdon, Strategic Management for Education Management (Manajemen Strategik untuk Manajemen Pendidikan), (Bandung: Alfabeta, 2009)

Ary Gunawan, Administrasi Sekolah Administrasi Pendidikan Mikro, (Jakarta: PT. Rineka Cipta,1996)

Anwar,Dedik Fatkul, Strategi pemasaran jasa Pendidikan dalam meningkatkan peminat layanan pendidikan, (Yogyakarta:UIN Sunan Kali Jaga,2014).

Ahmad D. Marimba, Pengantar Filasafat Pendidikan Islam, (Bandung: Al - Ma'arif, 1989)

Buchari Alma, Manajemen Pemasaran dan Pemasaran Jasa, (Bandung: Alfabeta, 2011)

Basu Swastha DH dan Ibnu Sukotjo, Pengantar Bisnis Modern, Edisi III, (Yogyakarta:LibertyYogyakarta, 1991),

Boyd, Walker, Larreche, Manajemen Pemasaran; Suatu Pendekatan Strategi dengan Orientasi Global, (Jakarta: Erlangga, 2000),

Buchori Alma, Pemasaran Strategik Jasa Pendidikan, (Bandung: Alfabeta, 2005)

Buchari Alma, Manajemen Pemasaran dan Pemasaran Jasa, (Bandung: Alfabeta, 2011) 
Charles W. Lamb, et. al, Pemasaran (marketing), (Jakarta: PT. Salemba Empat, 2001)

Crown Dirgantoro, Manajemen Strategik Konsep, Kasus, dan Implementasi, (Jakarta: PT Gramedia Widiasarana Indonesia, 2001),

David Wijaya, Pemasaran Jasa Pendidikan, (Jakarta: Salemba Empat, 2012)

Elytasari Suvidian, Strategi pemasaran Pendidikan untuk meningkatkan kepercayaan (Trust) Stakeholders di TK Amal Insani Depok Yogyakarta, (Yogyakarta :UIN, 2016).

Freddy Rangkuti, Analisis SWOT: Teknik Membenah Kasus Bisnis, (Jakarta: Gramedia, 2001)

Indo Yama Nazarudin dan Hemmy Fauzan, Pengantar Bisnis dan Manajemen,(Jakarta: UIN Jakarta Press, 2006)

Pengendalian, (Jakarta:Salemba Empat, 2007)

Muhaimin, dkk., Manajemen Pendidikan: Aplikasinya dalam Penyusunan RencanaPengembangan Sekolah/Madrasah, (Jakarta: Kencana, 2009).

Made Pidarta, Manajemen Pendidikan Indonesia, (Jakarta: Bina Aksara, 1988),

Marian Burk Wood, Buku Panduan Perencanaan Pemasaran, (Jakarta: PT. Indeks, 2009),

Mursid, Manajemen pemasaran, (Jakarta: PT Bumi Aksara, 2014)

Memilih Perguruan Tinggi Swasta di Medan, (Studi Kasus: Fakultas Ekonomi Universitas Al-Azhar Medan, 2008

M. Arifin, Filsafat Pendidikan Islam, (Jakarta: Bumi Aksara, 2000),

Muhibbin Syah, Psikologi Pendidikan dengan Pendekatan Baru, (Bandung: Remaja Rosdakarya, 2005), Edisi revisi,

Mudrajad Kuncoro, Strategi Bagaimana Meraih Keunggulan Kompetitif, (Jakarta: Erlangga, 2007),

Nanang Fattah, Sistem Penjaminan Mutu Pendidikan, (Bandung: PT Remaja Rosdakarya, 2012)

Ngalim Purwanto, Ilmu Pendidikan Teoritis dan Praktis, (Bandung: Remaja Rosda Karya,2011),

Rosady Ruslan, Aspek-Aspek Hukum dan Etika dalam Aktivitas Public Relations Kehumasan,(Jakarta: Ghalia Indonesia, 1995)

Rahman Syafi'ur, Strategi pemasaran jasa Pendidikan Madrasah dalam meningkatkan kompetensi lulusan, (Yogyakarta:UIN, 2015).

Rusadi Rulan, Manajemen Publik Relation Media Komunikasi, Konsep dan Aplikasi, (Jakarta:PT. Raja Grafindo Persada, 2008)

Syaiful Sagala, Manajemen Strategik dalam Peningkatan Mutu Pendidikan, (Bandung:Alfabeta, 2007)

Soufyan Assauri, Manajemen Pemasaran, (Jakarta: Rajawali, 1988),

Syafruddin, Manajemen Lembaga Pendidikan Islam, (Jakarta: PT. Ciputat Press, 2005)

Tsanawiyah Negeri Model Malang, (Semarang: Perpustakaan Fakultas Tarbiyah, 2011), h.34-35.

Tim Dosen Administrasi Pendidikan, Manajemen Pendidikan, (Bandung: Alfabeta, 2013), 
Suparlan Suhartono, Filsafat Pendidikan, (Yogyakarta: Ar-ruzz Media Group, 2009)

Tim Dosen Administrasi Pendidikan, Manajemen Pendidikan, (Bandung: Alfabeta, 2013),

Tjipto Fandi, Strategi Pemasaran, (Yogyakarta: Andi offset, 1999)

Glendy Tangkilisan, Bauran pemasaran jasa pendidikan pengaruhnya terhadap keputusan siswa dalam memilih sekolah di SMK N 1 Manado, (Manado: Universitas Sam Ratulangi Manado, 2014). 